\title{
WORKERS' COMPENSATION: The Historic Compromise COMPROMised?
}

\section{IAN MCKENNA}

The decision of Justice MacLean of the Alberta Court of Queen's Bench in Wilson v. Medicine Hat (City of) ${ }^{1}$ raises a fundamental issue about the relationship between the common law and workers' compensation legislation across Canada.

The case arose when six of the plaintiffs made claims to the Workers' Compensation Board of Alberta (WCB) that they had suffered injuries during the course of their employment due to their alleged exposure to methanol, lubrizol combustion products, and other chemicals. The WCB determined that the weight of evidence did not support a causal relationship between the workers' claimed multiple symptoms and the alleged occupational exposure to the various chemicals. Accordingly, the claimed symptoms did not arise out of, and occur in the course of, employment, and the workers were therefore not entitled to compensation under the Workers' Compensation Act. ${ }^{2}$

Denied compensation by the WCB and having exhausted all appeals under the Act, the workers and their spouses brought a common law claim before the Court of Queen's Bench for damages for injuries allegedly caused by the negligence of the various defendants. The defendants sought an order striking out the statement of claim based on various provisions of the Act. In particular, the defendants relied upon s. 16 which provides that:

16(1) No action lies for the recovery of compensation under this Act and all claims for compensation shall be determined by the Board.

16(2) This Act and the regulations apply in lieu of all rights and causes of action, statutory or otherwise, to which a worker, his legal personal representatives ... might become entitled against the employer of the worker by reason of the accident are, or might become, entitled against the employer of the worker by reason of any accident happening to the worker, and no action in respect of that accident lies against the employer.

Section 18 of the Act provides:

18(1) If an accident happens to a worker entitling him or his dependants to compensation under this Act, neither the worker, his legal personal representatives ... nor his employer has any cause of action in respect of or arising out of the personal injury suffered by, or the death of, the worker as a result of the accident

(a) against any employer, or

Associate Professor, Faculty of Management, University of Lethbridge, Lethbridge, Alberta. [1999] A.J. No. 269 (Q.B.), online: QL (AJ) [hereinafter City of Medicine Hat]. Related actions against the defendants were brought by other plaintiffs in cases 9608-00514, 9608-00515, 980800253, 9808-00307, and 9808-00332. 
(b) against any worker of an employer,

in an industry to which this Act applies when the conduct of that employer or worker that caused or contributed to the injury arose out of and in the course of employment in an industry to which this Act applies.

Furthermore, s. 12 of the Act provides that:

12(1) Subject to section 7, the Board has exclusive jurisdiction to examine, inquire into, hear and determine all matters and questions arising under this Act or the regulations and the action or decision of the Board thereon is final and conclusive, and is not open to question or review in any court.

The defendants relied on the judgements of the Alberta Court of Appeal in Budge v. Alberta (W.C.B. $)^{3}$ and the Supreme Court of Canada in Reference Re Sections 32 and 34 of the Workers' Compensation Act (Nfld.). ${ }^{4}$ In Budge, the Court ruled that s. 18(1) of the Act does not violate ss. 7 and 15(1) of the Canadian Charter of Rights and Freedoms. ${ }^{5}$

The defendants also raised the "historic trade-off" (or compromise) argument to support the position that the Act precludes common law action against them by the plaintiffs in the circumstances of this case. ${ }^{6}$ This argument, which found favour with the Newfoundland Court of Appeal in the Newfoundland Reference, suggests that the statutory exclusion of common law actions against employers by employees for injuries allegedly caused by the fault of the former was, and remains, the quid pro quo for the benefit flowing to workers from the statutory employer-funded, no-fault insurance scheme created to replace the old order. The Court of Appeal recognized that, while some workers might stand to receive lower awards under the no-fault compensation scheme than they would receive in a successful common law action against their employer, such disadvantages to particular workers or classes of worker can be viewed as a legitimate and inevitable ingredient of "the historic trade-off" that created, and helps to sustain, the workers' compensation system. ${ }^{7}$

[1991] 3 W.W.R. 1, (1991), 111 A.R. 228, 78 Alta. L.R. (2d) 193 (C.A.), rev'g [1987] 6 W.W.R. 217, 80 A.R. 207, (1987) 54 Alta. L.R. (2d) 97 (Q.B.) [hereinafter Budge]. (1990) 235 A.P.R. 181 (S.C.C.), affg 206 A.P.R. 16 (Nfld. C.A.) [hereinafter Newfoundland Reference].

Part I of the Constitution act, 1982, being Schedule B of the Canada Act, 1982 (U.K.), 1982, c. 11. The Court of Appeal ruled that the Court was bound by the decision of the Supreme Court of Canada in Newfoundland Reference, ibid. at 4.

As noted by MacLean J. in the City of Medicine Hat at paras. 4-6, the Alberta Act does not eliminate all rights and causes of action arising from an injury or disease occurring during the course of employment. Some specific actions are preserved and a right of action against a person other than an employer or employee is authorized and, if successful, provides for subrogation on the part of the Workers' Compensation Board. (See the Act, s. 17(1)). 
The historic trade-off argument has a common sense attraction and an element of validity. ${ }^{8}$ It is eminently sensible that a no-fault insurance scheme be preferred to the inefficient and frequently unfair system of tort law or of breach of contract, particularly in the form these took when workers' compensation was introduced into Canadian provinces early in the twentieth century. Reflecting on the role of tort law in the compensation of injuries and disease, Ison asserts:

Even if a system of compensation for disablement was being designed with malice, it would be hard to conceive of any system more inefficient than tort liability. ${ }^{9}$

Ison's point is that the cost to compensation ratio of tort liability, estimated to be in the region of 80 to 100 percent, is significantly higher than that of social security or nofault compensation schemes.

However, while a strong case can be made for some form of compromise that excludes or restricts common law action by employees in exchange for a no-fault insurance system of compensation, it is fallacious to conclude that the actual compromise must be one that precludes entirely the access of injured workers to the courts in respect of injuries allegedly caused during the course of employment. Nor does the recognition of a historic compromise require that the terms of such a compromise be immutable and unresponsive to the rapid and fundamental changes that have occurred in the world of work, of legal doctrine, of knowledge and perception of disease and injury, and of a variety of other social and economic factors. Such changes may justify a reappraisal, a renegotiation, and a refashioning of the historic compromise.

Particular concerns about the scope of the historic compromise arise when a worker is held not to be eligible for workers' compensation for an injury or disease that is ostensibly linked causally to the course of his or her employment. An example is a mental distress injury caused by an employer's wrongful dismissal of an employee. The Manitoba and the Ontario workers' compensation legislation expressly preclude compensation for mental stress caused by, inter alia, the discipline or dismissal of an employee. ${ }^{10}$ As we shall discuss later, the other Canadian jurisdictions exclude such injuries as a matter of board policy.

The first concern is the reason why injuries with this particular cause should be excluded from coverage by workers' compensation legislation or policy. A second issue is that, having been so excluded from no-fault insurance coverage, whether such injuries should be compensable by way of common law action in the courts.

8 T.G. Ison, Workers' Compensation in Canada, 2d ed. (Toronto: Butterworths, 1989) at 163, para. 8.1.2, accepts the historic trade off argument in his remarks, "one of the goals of the (workers' compensation) system is to avoid the costs of litigating over fault or degrees of fault."

" T.G. Ison, Compensation Systems for Injury and Disease: The Policy Choices, 2d ed. (Vancouver: Butterworths, 1994) at 123.

10 Workers' Compensation Acl, S.M. 1991-92, c. 36, s. 1 (1.1); Workplace Safety and Insurance Act, S.O. 1997 , c. 16, s. 13(5). 
There appears to have been no suggestion from workers' compensation boards and employers that the exclusion of such injuries from statutory compensation schemes should serve as a bar to common law action against employers for such injuries. Indeed, workers' compensation boards appear quite emphatic that such injuries not be compensated under workers' compensation schemes.

In Wallace v. United Grain Growers, " the defendant employer raised no defence of statutory bar to the action for wrongful dismissal and damages for mental distress caused thereby. ${ }^{12}$ Nor did provincial workers' compensation boards intervene to contest the plaintiff's right to a civil action for damages for mental distress allegedly caused by his employer in the course of his employment. This is to be contrasted with the interventions of most of the provincial workers' compensation boards in the Newfoundland Reference case supporting the statutory bar to civil actions. ${ }^{13}$ Accordingly, there appears to be no disagreement on the part of workers' compensation boards, nor on the part of provincial governments that injuries in like circumstances to Wallace are to be dealt with by the courts rather than by the respective workers' compensation boards. ${ }^{14}$

Rather more controversial than the statutory exclusion of mental distress caused by an employer's personnel decisions (such as dismissal) from workers' compensation schemes, is its exclusion by virtue of workers' compensation board policy in other provincial jurisdictions. ${ }^{15}$ The standard justification given by workers' compensation boards for these policies is that these injuries flow from "routine industrial relations action." 16 The issue of the use of administrative policies to limit the scope of a compensable accident under workers' compensation legislation will be discussed below. At this point, my intention is merely to provide an example of an alleged workplace injury which is deemed (whether by legislation or by administrative policy) not to be "an accident" for the purposes of workers' compensation regimes, and which may be compensable by civil action against the employer.

In City of Medicine Hat, MacLean J. was presented with another circumstance in which an alleged workplace injury was not an accident for the purposes of workers'

[1997] 3 S.C.R. 701; [1997] 9 W.W.R. 153; 152 D.L.R. (4th) I [hereinafter United Grain Grovers].

12 It is notable that no provincial workers' compensation board intervened in the United Grain Growers, in contrast to the Newfoundland Reference where most intervened to oppose the plaintiff's attempt to bring a common law action in respect of workplace injuries.

13 The Alberta Workers' Compensation Board was the defendant in Budge.

14 This is controversial, bearing in mind Ison's criticism of tort-based systems of injury compensation and the lack of certainty as to how the lower courts will apply the Supreme Court's decision in United Grain Growers.

is See Occupational Disease and Occupational Stress: Legislation and Policies 1998 (Mississauga: Association of Workers' Compensation Boards of Canada, 1998) [hereinafter AWCBC Survey]. See, for example, the Saskatchewan Workers' Compensation Board Policy \# 02/92 (as amended 04/96), p.1. It is notable that, in United Grain Growers, neither Lockwood J. of the Court of Queen's Bench, (1993), 87 Man. R. (2d) 161, nor the Supreme Court of Canada, supra note 11, shared the view that the employer's action was simply "a routine industrial relations action." 
compensation. The Act defines an "accident" for the purposes of compensation in a manner similar to that used in other jurisdictions:

s. 1(1)(a) "accident" means an accident that arises out of and occurs in the course of employment in an industry to which this Act applies and includes

(i) a wilful and intentional act, not being the act of the worker who suffers the accident;

(ii) a chance event occasioned by a physical or natural cause;

(iii) disablement; and

(iv) a disabling or potentially disabling condition caused by an occupational disease.

Justice MacLean noted the WCB's policy statement which reads:

"ARISES OUT OF AND OCCURS IN THE COURSE OF EMPLOYMENT"

(a) The Board interprets the statutory phrase "arises out of and in the course of employment" to mean:

(i) that the accident must be caused by some hazard which results from the nature, conditions or obligations of the employment

AND

(ii) that the accident must happen at a time and place, and, in circumstances consistent with and reasonably incidental to, the employment. Evidence must show that a causal relationship exists between the accident and the employment. ${ }^{17}$

MacLean J. noted that, because the definition of "accident" limits compensation to injuries "arising out of and occurring in the course of employment," certain circumstances might arise in which an employee might sue his employer for the alleged fault of the latter. MacLean J. cited the example of an employee who, outside his designated hours of work, returns uninvited to his place of work to retrieve his tool kit and is injured when he trips and falls into an unlit, unprotected, open stairwell. MacLean J. stated that the worker would not be entitled to workers' compensation for his injuries but would be entitled to take legal action against his employer, notwithstanding the "exclusive jurisdiction" clause of the $A c t .{ }^{18}$

MacLean J. reasoned that the type of injury in his example is outside the ambit of the Act and, accordingly, is "not controlled or limited in any way by the Act." 19 Such reasoning is consistent with what appears to have been the views of the Manitoba Workers' Compensation Board and the employer in United Grain Growers. Justice

17 WCB Policy Statement ADJ - 29 (02) (a) (b).

is Supra note 1 at para. 10.

19 Ibid. 
MacLean opined that the reference in s. 16(2) of the Act to "all rights and causes of action" by reason of "any accident" are limited by, and are subject to, both the statutory and the jurisdictional exceptions under Board policy. The effect of such an approach is to render inoperative the statutory exclusions of rights of action in the same manner as both MacLean J.'s example of the worker injured at his place of work but not in the course of his employment and of the mental distress caused to the employee by his dismissal in United Grain Growers.

The Court applied the foregoing reasoning in City of Medicine Hat in circumstances where the WCB had not found any causal relationship between the plaintiffs' symptoms and any workplace hazards or conditions. MacLean J. noted that, in their policy statement refining the definition of "accident," the WCB specifies that, to be compensable, the "accident" must be "caused by" hazards, etc., of the workplace and that the evidence must show that "a causal relationship exists."

MacLean J. observed that terms such as "caused by" and "a causal relationship exists" are subject to a diversity and breadth of legal meaning and approaches. $\mathrm{He}$ noted that "there is a body of learned opinion that will say causation may not require any significant degree of scientific proof but that causal connection may be found by inferences arising out of the circumstances and may be in the nature of even mere possibilities or mere probabilities from an evidentiary point of view."20

The Court discussed the nature and standard of proof of causation adopted by the WCB and concluded that, while the Board adopts a "benefit of the doubt" principle in favour of the worker when evidence of causation is relatively equal, claimants are not entitled to compensation where, in the Board's opinion, the evidence fails to reach the threshold of "relatively equal."21 Justice MacLean concluded that, while the WCB is entitled to determine whether the evidence meets the standard required to entitle a worker to compensation under the $A c t$, such a determination does not entitle employers or the Board to invoke the exclusion of common law action provided in s. 16(2) of the Act. The Court reasoned that s. 16(2) applies only in respect of any accident happening to the worker and that, by finding insufficient evidence of causation, the Board is ipso facto determining that the worker's injury is not an accident within the meaning of ss. $1(1)$ and $16(2)$ of the Act.

Essentially, the Court treated the circumstances in the City of Medicine Hat case in the same manner as those in United Grain Growers. That is, both are seen as circumstances in which either statute or WCB policy excludes claimants from entitlement to compensation and also prevents employers from invoking the bar to legal action provided by s. $16(1)$. 72 D.L.R. (4th) 289 [hereinafter Snell]; and Mackie v. Wolfe (1994) 21 Alta. L.R. (3d) II, 153 A.R. 81 (Alta. Q.B.), affd (1996) 41 Alta. L.R. (3d) 28, 184 A.R. 339 (C.A.) as examples of the breadth of approaches to legal causation. 
MacLean J.'s approach is problematic in certain respects. There is a persuasive body of opinion that suggests that the intention of s. 16(2) of the Act is to shield employers from legal action as the quid pro quo for the expenses they incur in funding the nofault compensation scheme. Furthermore, the Act entrusts to the exclusive jurisdiction of the WCB and to the statutory processes of adjudication, review, and appeal, the determination of such matters such as eligibility for compensation (including the determination of causation).

Arguably, in both granting such broad, exclusive powers to the WCB and in excluding the access of claimants to the courts, the Legislature must not have intended to leave employers open to law suits from any unsuccessful claimant dissatisfied with denial of his/her claim due to a lack of evidence of causation. It can be argued that, if a claimant could launch a civil suit after a negative finding of causation by the WCB, she/he would undermine the foundations of the no-fault system and would effectively endanger the historic compromise that allowed for the creation of workers' compensation schemes in Canada.

On the other hand, there is also merit in Justice MacLean's approach. While s.16(2) of the $A c t$ does preclude civil action in respect of any accident happening to a worker, an accident only occurs if, inter alia, the WCB determines that it has occurred. If, as in City of Medicine Hat, the board rules that no "accident" took place, it is entirely logical on its face for the Court to interpret s. 16(2) as to be of no effect in such circumstances. Indeed, the courts have traditionally been unwilling to deny individuals remedies in the courts for the alleged wrongs of others in the absence of "manifestly clear" statutory language to this effect. ${ }^{22}$ It can scarcely be argued that the $A c t$ provides manifestly clear language of the nature contemplated by the Supreme Court of Canada.

It can also be advanced in support of MacLean J.'s judgment that the historic tradeoff argument rests on the obsolete notion that an employer's expenditure on workers' compensation premiums is exclusively a cost or burden to the employer and solely a benefit to workers. This "zero-sum-game" ideology of employment relations was dominant at the dawn of workers' compensation in Canada in the early twentieth century and retains significant influence among courts and arbitrators today.

Nevertheless, Langille has provided persuasive criticism of an approach that portrays any expenditure or concession by an employer to workers as automatically and exclusively a burden or constraint on the employer. ${ }^{23}$ While precise costs and benefits are difficult to quantify, contemporary research suggests that the rehabilitation of workers through workers' compensation and other insurance programs can be of benefit not only to workers but also to employers. The permanent or long-term loss of skilled (per Estey J.).

23 B. Langille, "Equal Partnership in Canadian Labour Law" (1983) 21:3 Osgoode Hall L.J. 496. See in particular, ibid. at 508-11 where the author discusses the mutual benefit to workers and management of the latter's legal duty to bargain in good faith. 
workers through injury and disease is recognized today as costly to employers when the cost of hiring and training of replacement workers is taken into account.

Furthermore, since the dawn of workers' compensation in Canada, provincial legislators and workers' compensation boards have developed an increasingly important mission of promoting greater health and safety in workplaces. Premiums and resources are structured not only to underwrite the costs of compensation and rehabilitation of workers but to encourage employers in the prevention of workplace accidents and in the timely return of workers to their work. ${ }^{24}$ There is ample evidence of the fact that the indirect costs of workplace accidents to employers substantially outweigh the costs of premiums. Workers' compensation premiums are not merely a cost and a burden to employers but are an investment in a program designed to reduce the incidence and the negative impact of workplace accidents and diseases for the benefit of employers as well as of workers and the broader society. ${ }^{25}$

Arguably, the new purposes and realities of workers' compensation require a reexamination and renegotiation of the historic compromise, and Maclean J.'s approach in City of Medicine Hat may help pave the way. A key concern in the renegotiation of such a compromise is the role of workers' compensation boards. In City of Medicine Hat, MacLean J. revealed his unease with the role of the WCB in the determination of causation with respect to workers' claims under the Act with his remarks:

The Board is a statutory body whose primary purpose is to protect employers by bringing uniformity, efficiency, expeditiousness and cost-savings measures to selected accidents which occur in the employer worker relationship. It accomplishes this purpose by restricting rights of workers to have their right to compensation and the extent of their compensation determined by the Board. It cannot be said that the Board is independent as far as the worker is concerned. It is a Board set up to protect employers. ${ }^{26}$

It is evident that MacLean J. is concerned that, given the WCB's primary allegiance to employers and its substantial discretion in establishing causation and the eligibility of workers for compensation, it cannot be relied upon to render an impartial judgment or one that is perceived by workers to be impartial.

MacLean J.'s concern about the impartiality of the WCB is raised by Ison, who recognizes that political pressure can influence the extent to which workers' compensation boards will compensate or externalize the costs of workplace accidents. The author contends that, while, in theory, workers' compensation boards are supposed

See Ison, supra note 9 at 63, who suggests that "under-recognition of the occupational etiology of diseases undermines prevention."

25 See, for example, Ontario, New Directions for Workers ' Compensation Reform (Toronto: Minister Without Portfolio Responsible for Workers' Compensation Reform, 1996). The report, at 6, specifies the key principles of the new Ontario Workplace Safety and Insurance Act, 1997, "prevention first, return to work if possible, rchabilitation when needed and compensation as required."

26. Supra note 1 at para. 19; MacLean J. was considering the matter of issue estoppel raised by the defendants. 
to be insulated from political interference by the executive branch of government in their policies and practices, in practice, political interference does operate on boards. ${ }^{27}$ Ison notes that the most well-known form of political interference with workers' compensation boards in Canada relates to employer assessment rates. He states:

The legislation provides for revenues to be adjusted according to the total cost of benefits while the political pressures tend to require that benefits should be adjusted to accord with predetermined level of revenues. ${ }^{28}$

The concern about the exclusive jurisdiction of workers' compensation boards is heightened by the different principles of the proof of causation that have developed in the courts on the one hand and in workers' compensation boards on the other. Ison identifies the political pressures placed on workers' compensation boards that "demand an excessive standard of proof in claims that allege industrial causation" of disease or injury. ${ }^{29}$ Ison contends that workers' compensation systems in Canada are biased toward finding that no workplace cause of disease and injury exist due to the overcautious medical/scientific literature regarding etiology. ${ }^{30}$ His concerns are heightened by his opinion that "our knowledge of the etiology of disease is probably becoming obsolete at a faster pace than it is expanding." 31

The emphasis on scientific proof of causation in workers' compensation claims stands in contrast with the approaches recently developed in the courts. In Snell, Sopinka J. for the Supreme Court of Canada stated:

In some circumstances, an inference of causation may be drawn from the evidence without positive scientific proof. ${ }^{32}$

The Supreme Court held further that

It is not essential to have a positive medical opinion to support a finding of causation. It is not speculation but the application of common sense to draw such an inference where, as here, the circumstances, other than a positive medical opinion, permit. ${ }^{33}$

Furthermore, as the Supreme Court of Canada ${ }^{34}$ and Ison ${ }^{35}$ observe, the scientific test of certainty or of very high degrees of probability to establish causation in workers'

Ison, supra note 9 at 188.

lbid.

Ison, supra note 9 at 9 . Ison draws on the work by T.H. Murray, "Regulating Asbestos: Ethics, Politics and the Values of Science" in R. Bayer, ed., The Health and Safety of Workers: Case Studies in the Politics of Professional Responsibility (New York: Oxford University Press, 1988) 280.

Ison, supra note 9 at 62 .

Ibid.

Supra note 20 at 330.

Ibid. at 336.

See both Snell and Athey, supra note 20.

Ison, supra note 9 at 63 . 
compensation cases is at variance with the balance of probability test applied by courts in civil actions.

The foregoing discrepancy between the approaches to establishing causation applied by the courts and workers' compensation boards lends weight to MacLean J.'s concern that, in such cases as City of Medicine Hat, the language of the Act should not be interpreted in a manner that confers on the WCB exclusive jurisdiction to establish both the test of causation and the weighing of evidence to determine whether the test has been met.

Further concerns apply to the scope of compensable injuries recognized by the WCB and by the other provincial workers' compensation boards in Canada. The AWCBC survey $^{36}$ indicates that most workers' compensation boards in Canada provide compensation and rehabilitation services for mental stress caused by a traumatic workplace event (such as witnessing an armed bank robbery). However, it is difficult, in practice, for claimants to establish causation with respect to chronic stress or to emotional exhaustion (burnout) associated with their work. ${ }^{37}$

This article is not the place for a detailed discussion of the merits of WCB policy on the compensation of such injuries. However, it is of great concern that workers might be denied both workers' compensation and access to the courts for stress and burnout injuries, especially in view of the substantial empirical evidence that such injuries are commonplace in North America. ${ }^{38}$

The exclusion of such injuries from both insurance coverage and from adjudication in the courts can scarcely be justified by appealing to the historic compromise. At the dawn of workers' compensation in Canada, workplace mental stress and burnout, although referred to in some literature, either did not exist or was not widely recognized as a commonplace workplace phenomenon. ${ }^{39}$ Now that there exists substantial evidence of widespread stress and burnout at work, it is clear that the historic compromise must be renegotiated. A key element of such renegotiation should be clear, fair, and functional criteria and processes for determining causation of workplace stress

Supra note 15 at $59-60$.

37 Saskatchewan has a policy (\#02/92 amended 04/96) which provides guidelines relating to the compensation of chronic stress.

38 The recent literature includes the following: C.L. Golembiewski, Global Burnout: A Worldwide Pandemic Explored by the Phase Model (Greenwich, Ct.: JAI Press, 1996); C.L. Cooper \& M.J. Smith, eds., Job Stress and Blue Collar Work (Chichester: John Wiley \& Sons, 1985); T. Newton, J. Handy \& S. Fineman, Managing Stress: Subjectivity and Power in the Workplace (London: Thousand Oaks, 1995); J.C. Quick, L.R. Murphy \& J.J. Hurrell Jr., eds., Siress and Well-being at Work (Washington, D.C.: American Psychological Association, 1992); see, in particular, P. Carayon, "A Longitudinal Study of Job Design and Worker Strain: Preliminary Results," ibid. at 19.

While research on mental stress is comparatively recent, Sir William Osler (1849-1919) wrote about the problems facing physicians and equated "stress and strain" with hard work and worry; see "The Lumeian Lectures on Angina Pectoris," The Lancet (1910), vol. I at 698. Also, Breay (1913) published an article on "overstrain" among nurses of that period. Both articles are referred to in C. Spielberger, Understanding Stress and Anxiety (New York: Harper \& Rowe, 1979) at 7. 
and burnout. As MacLean J. suggests, if the WCB is the sole arbiter of causation, without scrutiny by the courts, there is a danger that claims will be denied, having been unduly influenced by the rigorous standard of scientific certainty which serves the interest of the Board and participating employers in minimizing the burden of insurance premiums.

A strategy of denying stress claims by imposing unduly rigorous tests of causation is inconsistent with the proclaimed workers' compensation board priority: the prevention of workplace injuries and diseases. While there is substantial evidence of widespread mental stress and burnout caused by workplace conditions, workers' compensation boards have foreclosed the possibility of compensation for such claims on the assumption that the rigorous standard of scientific proof will never be met in individual cases. While this may be true, it is highly controversial that workers' compensation boards should be applying such a rigorous standard of proof of causation at variance with judicial standards.

\section{CONCLUSION}

MacLean J.'s decision in the City of Medicine Hat is not so much a threat to the historic compromise as a signal that such a compromise is in need of re-evaluation and of renegotiation. The, at best, ambiguous language of the Act with respect to the definition of an accident is simply another example of the traditional judicial reluctance to deny access to the courts for the remedy of alleged civil wrongs without clear, unambiguous statutory language.

It is not suggested here that access to the courts in cases like City of Medicine Hat should replace workers' compensation as the method of compensating workplace accidents. As Ison argues, workers' compensation schemes are substantially more efficient than civil action in tort (or contract) for the compensation of workplace injuries and disease. Nevertheless, access to the courts appears to have an important role in checking, in some measure, the under-compensation of workplace injuries by the application of excessively rigorous tests of causation and by the blanket denial of claims in respect of specific types of injury such as mental stress and burnout.

To be sure, such matters should be addressed and resolved not in the courts, but by the respective workers' compensation systems across Canada. However, the political pressures on workers' compensation boards are at the root of the rigorous tests of causation and of the denial of claims for certain types of injury. This has led to the under-compensation of injuries and to the externalizing of their costs onto workers and onto society at large. ${ }^{40}$ Within a system of compensation run for the interests of employers, there is little incentive to change in spite of the fact that, as Korten observes, ${ }^{41}$ the externalization of costs disrupts the efficient functioning of the market. at $90-91$, where the author contends that "full-cost" pricing is an essential element of efficient markets. 
One effect on the workers' compensation system is to reduce the incentive on employers to take preventative measures.

Ison makes a persuasive case for a comprehensive system of compensation, rehabilitation, and prevention of disability that excludes the inefficient and unfair system of tort and avoids the irrational and contentious distinction between workplace and other accidents. ${ }^{42}$ However, until there is political support for such a scheme, MacLean J.'s approach in City of Medicine Hat offers at least some protection to workers and to the broader society against workers' compensation policies and practices which externalize from employers the costs of workplace accidents and disease. It also provides an incentive to the politicians within and without workers' compensation boards to renegotiate the historic compromise in order to take into account changed legal doctrines of causation, the new priority given to accident prevention, the need for market incentives, and the new wave of industrial diseases such as mental stress and burnout, which compensation boards have ignored for too long. 